\title{
INSECTS ASSOCIATED WITH DECOMPOSING AFRICAN OIL BEAN SEED (Pentaclethra macrophylla BENTH.) IN TWO ENVIRONMENTS IN AWKA, ANAMBRA STATE, NIGERIA.
}

\author{
Ekejiuba Emeka Emmanuel \\ Department Of Zoology, Nnamdi Azikiwe University \\ Awka Anambra State Nigeria \\ Emmaemeka141@gmail.com \\ Ewuim Sylvanus Chima \\ Department Of Zoology,Nnamdi Azikiwe University \\ Awka Anambra State Nigeria \\ cewuim@gmail.com \\ DOI: $10.31364 /$ SCIRJ/v7.i4.2019.P0419XX \\ http://dx.doi.org/10.31364/SCIRJ/v7.i4.2019.P0419XX
}

\begin{abstract}
Insect fauna populations during the decomposition of sliced fermented African oil bean seeds ugba in two environments were studied in Awka, Anambra State, Nigeria. The study was carried out for eight weeks in the months of April to June, 2018. During the study period, the insects associated with the decomposing oil bean seeds were collected with sweep net and hand-picking methods. T-test was used to analyse the relative abundance of the insects collected between the two environments at $5 \%$ significance level. Species diversity was also calculated using Shannon Wiener Index of Diversity. The individual insects collected were identified into five (5) orders, eighteen (18) genera and twenty-one (21) species. A total of 392 insects were collected from the study and the total number of insects attracted to asynanthropic environment (218) was higher than those of synanthropic environment (174). The results further showed that out of the five insect orders captured, Coleoptera recorded the highest number of insects in both environments (241), while Blattodea and Hemiptera had the least number of insects (6) each. There was no significant difference between the insect orders attracted to asynanthropic and synanthropic environments $(P=0.16)$ but there was significant difference between the total number of insects caught from the different orders in both environments $(\mathbf{P}=\mathbf{0 . 0 0})$. The relative occurrence of these insects suggests that decaying ugba is a convenient feeding and oviposition medium for many insects.
\end{abstract}

Index Terms- ugba, insects, decomposition, synanthropic, asynanthropic, relative abundance.

\section{INTRODUCTION}

$U g b a$ is the Igbo name for sliced fermented African oil bean seed (Pentaclethra macrophylla Benth.).The African oil bean seed is called several names in Nigeria, such as Apara by the Yoruba, Ugba or Ukpaka by the Igbo (1). It is consumed mostly in the eastern states of Nigeria as a local delicacy popularly known as "African salad" prepared with oil, pepper, fish and salt and also prepared with tapioca, stockfish and garden eggs. It can be eaten with boiled or roasted yam and cocoyam (2) and (3). It is a traditional food generally prepared in homes as a small family business (4). In many Eastern communities in Nigeria, ugba is consumed as a meat analogue due to its high protein content, the locally prepared $u g b a$ is done through a mixed wild bacteria fermentation of the sliced, boiled and soaked African oil bean seeds (5). Its raw seeds are bitter and contain antinutritional factors like paucine, cyanide, oxalate, saponin, phytate and tannins (5), (7) and (6).

The preparation method for ugba varies from one place to another resulting in a non-uniform product (9). It can be produced traditionally by boiling the seeds overnight for easy removal of the seed coat (4). The cotyledons are sliced and cooked until they are soft with reduced bitter taste. According to (7), the sliced $u g b a$ is washed about 5 times or more and fermented for 3 days. (4), reported that the cooked, processed and fermented seed of $u g b a$ is used to prepare some delicious African soup and sausages for eating different staples. (4) also noted that it is a rich source of vitamins and minerals, having a high demand for local and export consumption. 
Insects are strategic in the welfare of man and constitute a major component of the earth's biodiversity with their species richness or diversity exceeding that of any known group of extant organisms (10). The study of insects in the ecosystem has led to the discoveries of ecological roles insects play such as; pollinating flowers, organic matter recycling and being useful in scientific researchers relating to biology (11). Insects that recycle organic matter play useful roles in the decomposition of plants and animals which help to replenish the soil nutrients (12). This contributes very immensely to the continuity of the earth (2). Food contamination by insect organisms remains one of the major public health problems globally, the endemicity of food-borne diseases has led to high mortality in affected areas (4).Insects are food pests, in that they compete for or damage food resources, decreasing the amount available and/or acceptable for human consumption (12). (11) opined that compared with beneficial insects, injurious insects are very numerous. According to (13), these insects can infest our food through; physical attack, mechanical transmission, and production of toxins and allergens by the insects themselves, leading to conditions such as nausea, intestinal trauma and allergic reactions. Ambient temperature, season, and microclimate of the postmortem habitat also play major roles in the determination of the invertebrate assemblage on decaying animal and plant materials (14). Thus, it is crucial to examine seasonal insect activity on decomposing plants and animal materials in specific geographic regions and various habitats within these regions (14).

Some Information documented on oil bean seed (P. macrophylla Benth.) include: The Biotechnology of ugba, a Nigerian Traditional Fermented Food Condiment (15), Effect of Processing methods on the quality of ugba (18),Bacteria Species Associated with $u g b a$ (13), Incidence of enteric pathogens in $u g b a$, a traditional fermented food from African oil bean seed (16), Effect of African oil bean seed on Plasma Cholesterol level in Rats (17) among many others. However, literatures are scarce on insects associated with decaying fermented African oil bean seed, resulting in paucity of information in this area, hence there is a need to study insect composition and diversity on this important food condiment as the result will aid in the field of entomotoxicology.

\section{OBJECTIVES}

- $\quad$ Collect and rear to adult stage, insects larvae found on the decomposing oil bean seeds.

- $\quad$ Identify the insects to species level

- Determine their relative abundance and diversity on the decomposing oil bean seeds

\section{MATERIALS AND METHODS}

Two sites were used to carry out the comparative study, a fallow plot behind a privately owned students' hostel and an unoccupied room with cemented floor, both sites are in Ifite - Awka, Anambra State. The study site (Ifite - Awka), is located geographically in Awka North, Anambra, Nigeria. The geographical coordinates of the study area is $6^{\circ} 15 \mathrm{~N}, 7^{\circ} 5 \mathrm{E}$ and $72 \mathrm{~m}$ above sea level using Garmin model GPS map76CS $\mathrm{C}_{\mathrm{x}}$, and about $50 \mathrm{~m}$ away from residential homes. Awka is the capital of Anambra State. Strategically, Awka is midway between two major cities in Northern Igboland, Onitsha and Enugu and is located in the lowland rain forest zone of Southern Nigeria. Awka is located between latitude $5^{\circ}$ and $6^{\circ} 25^{\prime}$ and longitude $7^{\circ} \mathrm{E}$ and $8^{\circ} \mathrm{E}$ with the town stretching for $8 \mathrm{~km}$ in an East -West direction along the Enugu-Onitsha expressway and about $5 \mathrm{~km}$ in a North-South orientation (19).

\section{* Experimental Sites}

What constituted the synanthropic environment was an empty $24 \mathrm{~m}$ by $12 \mathrm{~m}$ room with cemented floor. The asynanthropic environment was a fallowed plot which has been left uncultivated for a period of three years. The soil is of loamy type and land had ridges as a result of former cultivation activities on it years back. The size of plot is $112440 \mathrm{~m}^{2}$. Weed species found on the fallow plot as identified by the Herbarium unit of Botany Department, Nnamdi Azikiwe University, Awka, were Ageratum conyzoides (Linnaeus.), Pennisetum pedicellatum (Linnaeus.), Tridax procumbens (Linnaeus.) and Mimosa pigra (Linnaeus.), with Tridax procumbens being dominant. 


\section{* Experimental Design}

40kg of sliced fermented African oil bean seeds $(u g b a)$ were placed in twenty, six metres depth containers, such that the $u g b a$ appreciates approximately to the brim of the container. Ten containers each containing the 40kg ugba were place in the asynanthropic and synanthropic environments at a distance of 4 metres from each other, to ensure that insects from one specimen does not enter the other specimen due to close proximity. For the synanthropic specimens, they were kept such that sunlight penetrates into the well ventilated room while preventing the entrance of rainwater by closing the windows when it rains. The asynanthropic specimens were covered with wire gauze of $1-2 \mathrm{~cm}$ mesh size to exclude bigger vertebrates (non-target organisms) from eating the specimen. The specimens were also covered whenever rainfall was suspected in the day and always at night in case it rains mid-night, but exposed to other weather elements. The temperature and relative humidity were recorded with Tinytag datalogger (Gemini Dataloggers, UK).

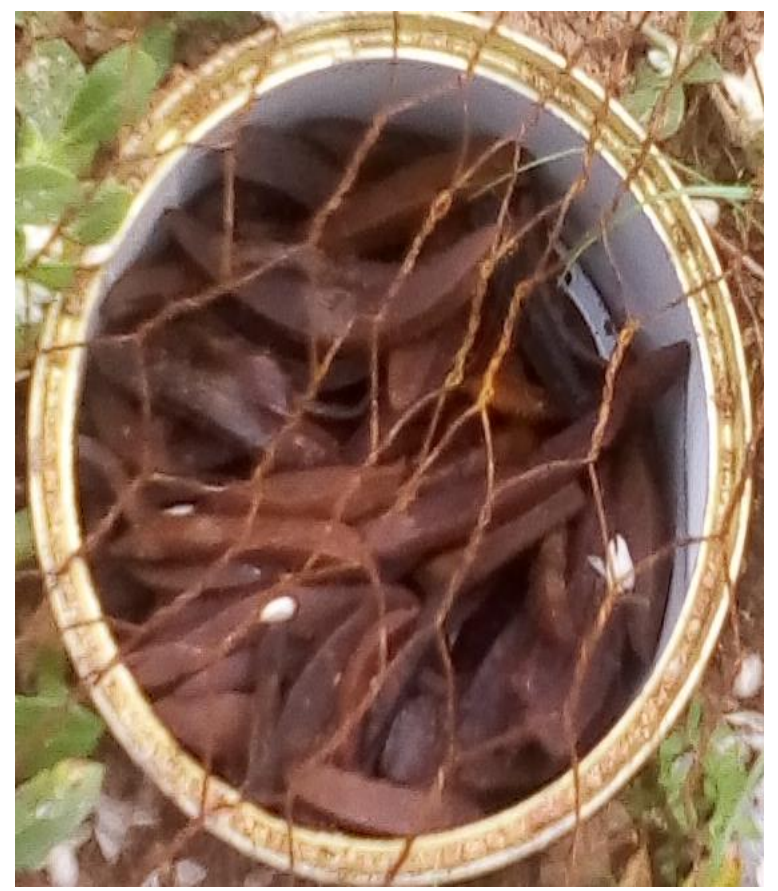

Plate 1: Specimen at initial decomposition stage

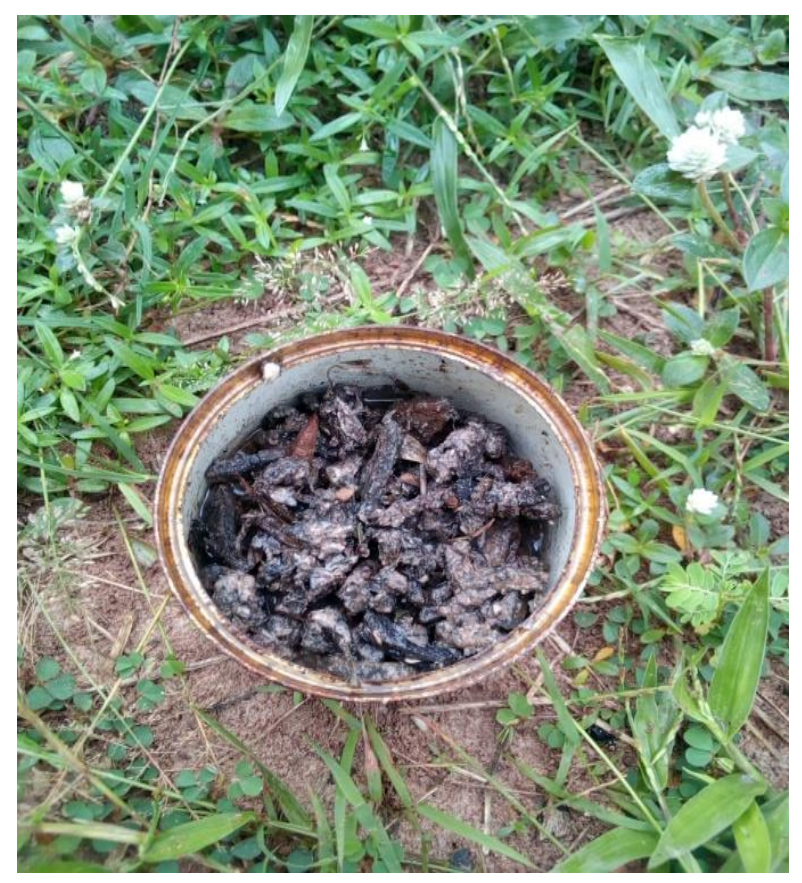

Plate 2: Specimen in advanced decomposition stage

\section{* Insects Collection and Preservation}

Adult insects attracted to the decaying sliced fermented oil bean seed were collected with sweep net and hand picking methods using fine brush daily for the first two weeks. Subsequent collections were made at the interval of three days till complete decomposition of the fermented seeds. Larvae observed were collected with the aid of fine brush and reared to adult stage. The entomological procedure for rearing larvae was followed until the emergence of adult insects. All species collected in the study were preserved in 5\% alcohol solution. 


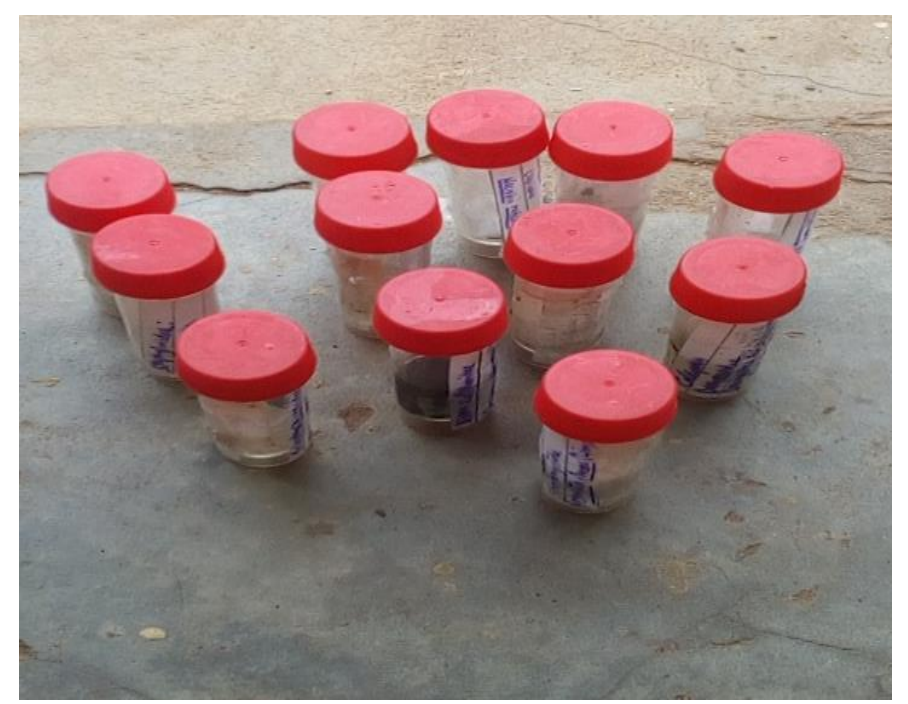

Plate 3: Collected and preserved insects from the study

\section{* Rearing of larvae}

The twelve larvae collected from the decomposing fermented oil bean seed in the asynanthropic environment were reared, following the entomological procedure for larvae rearing. The larvae rearing were achieved with a transparent jar which was one-quarter filled with substrate. The substrate was formulated from a mixture of wood saw dust and sandy soil as adopted from (20) the mixture was heated in an aluminium pot for thirty minutes to ensure that other microarthropods and pathogens were killed. The lids of the containers were guarded with mosquito net tightly held with the jar cover whose surface has been removed; this helped to prevent the escape of larvae and adult flies and also to prevent other flies from getting into the containers as reported by (21).The larvae sampled for rearing purpose were placed on rearing media which were some decaying fermented African oil bean seed. Observations were made several times to note changes in larvae, pupation emergence data and subsequent data of adult emergence. Larvae successfully reared were those of the Drosophilidae family (Drosophila sp.) and family Muscidae (Musca domestica). 


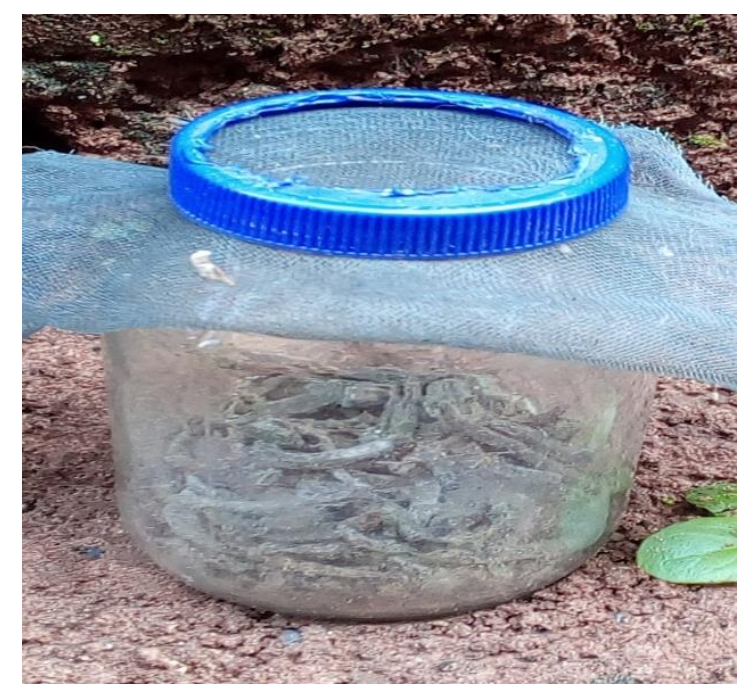

Plate 4: Set up for larvae rearing in a cool humid place

\section{* Identification of Insects Collected}

The adult insects collected were sorted into their various taxonomic groups and the voucher specimens kept for further studies. Some of the specimens were identified using previously labeled species in the laboratory and the rest were sent for either identification or verification of identification in the Department of Crop Protection and Agricultural Research, Ahmadu Bello University, Zaria, Nigeria.

\section{- Data Analysis}

T-test was used to compare the relative abundance between the two environments using SPSS computer Software package (Version 20)at 5\% significance levels. Species diversity was calculated using Shannon Wiener Index of Diversity.

Formula:

$\mathrm{H}=-\sum \mathrm{pi} \times \ln (\mathrm{pi})$

$\mathrm{J}=\frac{\mathrm{H}}{\mathrm{H}^{\prime}}$

Where:

H=Shannon's Diversity index

pi $=\frac{\text { Number of individuals of species }(i)}{\text { Total number of samples }}$

$\mathbf{S}=$ Species richness

$\mathbf{H}^{\prime}=$ Maximum Diversity possible

$\mathbf{J}=$ Evenness

\section{RESULTS}

* Insect collected from decomposing African oil bean seed in asynanthropic environment in Awka, Anambra State from April to June, 2018.

A total of 218 insects were caught in the decomposing African oil bean seed in the asynanthropic environment. They belong to five insect orders namely: Coleoptera, Hymenoptera, Diptera, Blattodea and Hemiptera (Table 1). Thirteen families with 16 genera and 18 species of insects were attracted to decomposing African oil bean seed in the asynanthropic environment. Coleoptera had the highest relative abundance $(69.72 \%)$ followed by Hymenoptera $(18.35 \%)$ while Blattodea and Hemiptera had the least $(0.46 \%)$. The result also showed that the order Coleoptera recorded the highest total number of insects (152) followed by Hymenoptera (40) while Blattodea and Hemiptera had the least (1). There was significant difference between the total number of insects caught from the different orders in the asynanthropic environment $(\mathrm{P}=0.00)$. 
Table 1: Relative abundance of insects collected from the Asynantropic environment

\begin{tabular}{|c|c|c|c|c|c|}
\hline Order & Families & Genera & Species & Total & $\begin{array}{c}\text { Relative } \\
\text { abundance }(\%)\end{array}$ \\
\hline \multirow[t]{10}{*}{ Coleoptera } & Dytscidae & Hydrovatus & Hydrovatus sp. & 21 & 9.63 \\
\hline & Scarabaeidae & Onthophagus & $\begin{array}{l}\text { Onthophagus } \\
\text { bituberculatus }\end{array}$ & 27 & 12.39 \\
\hline & & & $\begin{array}{l}\text { Onthophagus gazelle } \\
\text { F. }\end{array}$ & 31 & 14.22 \\
\hline & Tenebrionidae & Tribolium & $\begin{array}{l}\text { Tribolium castaneum } \\
\text { Herb. }\end{array}$ & 16 & 7.34 \\
\hline & Dermestidae & Anthrenocerus & $\begin{array}{l}\text { Anthrenocerus } \\
\text { australis L. }\end{array}$ & 13 & 5.96 \\
\hline & & Cerotoma & Cerotoma trifurcate & 10 & 4.59 \\
\hline & Nitidulidae & Aethenia & Aethenia sp. & 8 & 3.67 \\
\hline & Carabidae & Hyparpalus & Hyparpalus sp. & 6 & 2.75 \\
\hline & Cleridae & Necrobia & Necrobia rufipes & 20 & 9.17 \\
\hline & & & Sub total & 152 & 69.72 \\
\hline \multirow[t]{5}{*}{ Hymenoptera } & Braconidae & Cardiochiles & Cardiochiles sp. & 8 & 3.67 \\
\hline & Formicidae & Paratrechina & Paratrechina sp. & 11 & 5.05 \\
\hline & & Pheidole & Pheidole sp. & 15 & 6.88 \\
\hline & & Acantholepis & Acantholepis sp. & 6 & 2.75 \\
\hline & & & Sub total & 40 & 18.35 \\
\hline \multirow[t]{3}{*}{ Diptera } & Drosophilidae & Drosophila & Drosophila sp. & 6 & 2.75 \\
\hline & Muscidae & Musca & Musca domestica & 18 & 8.26 \\
\hline & & & Sub total & 24 & 11.01 \\
\hline \multirow[t]{2}{*}{ Blattodea } & Blattidae & Blatella & Blatella sp.(nymph) & 1 & 0.46 \\
\hline & & & Sub total & 1 & 0.46 \\
\hline
\end{tabular}




\begin{tabular}{|l|l|l|l|c|c|}
\hline Hemiptera & Lygaeidae & Dieuches & $\begin{array}{l}\text { Dieuches } \\
\text { (nymph) }\end{array}$ & sp. & 0.46 \\
\hline & & & Sub total & $\mathbf{1}$ & $\mathbf{0 . 4 6}$ \\
\hline & & & Grand Total & $\mathbf{2 1 8}$ & $\mathbf{1 0 0}$ \\
\hline
\end{tabular}

Insect collected from decomposing African oil bean seed in synanthropic environment in Awka, Anambra State from April to June, 2018.

A total of 174 insects were caught in the decomposing African oil bean seed in the synanthropic environments. They belong to five insect orders namely: Coleoptera, Hymenoptera, Diptera, Blattodea and Hemiptera (Table 2). Thirteen families belonging to 18 genera and 19 species of insects were attracted to decomposing African oil bean seed in the synanthropic environments. Coleoptera had the highest relative abundance $(51.25 \%)$ followed by Hymenoptera $(22.41 \%)$ while Blattodea and Hemiptera had the least (3.45\%). The result also showed that the order Coleoptera recorded the highest total number of insects (89) followed by Hymenoptera (39) while Blattodea and Hemiptera had the least (6). There was significant difference between the total number of insects caught from the different orders in the synanthropic environment $(\mathrm{P}=0.00)$.

Table 2: Relative Abundance of Insects Collected from the Synantropic Environment

\begin{tabular}{|c|c|c|c|c|c|}
\hline Order & Families & Genera & Species & Total & $\begin{array}{c}\text { Relative } \\
\text { abundance } \\
(\%)\end{array}$ \\
\hline \multirow[t]{8}{*}{ Coleoptera } & Dytscidae & Hydrovatus & Hydrovatus sp. & 18 & 1.34 \\
\hline & Scarabaeidae & Onthophagus & $\begin{array}{l}\text { Onthophagus } \\
\text { bituberculatus }\end{array}$ & 19 & 10.92 \\
\hline & & & $\begin{array}{l}\text { Onthophagus } \\
\text { gazelle } \mathrm{F} \text {. }\end{array}$ & 11 & 6.32 \\
\hline & Tenebrionidae & Tribolium & $\begin{array}{l}\text { Tribolium } \\
\text { castaneum } \\
\text { Herb. }\end{array}$ & 5 & 2.87 \\
\hline & Dermestidae & Anthrenocerus & $\begin{array}{l}\text { Anthrenocerus } \\
\text { australis L. }\end{array}$ & 8 & 4.6 \\
\hline & & Cerotoma & Cerotoma trifurcate & 5 & 2.87 \\
\hline & Nitidulidae & Aethenia & Aethenia sp. & 7 & 4.02 \\
\hline & Carabidae & Hyparpalus & Hyparpalus sp. & 4 & 2.3 \\
\hline & \multirow[t]{2}{*}{ Cleridae } & \multirow[t]{2}{*}{ Necrobia } & Necrobia rufipes & \multirow[t]{2}{*}{12} & \multirow[t]{2}{*}{6.9} \\
\hline & & & (De Geer) & & \\
\hline & & & Subtotal & 89 & 51.25 \\
\hline Hymenoptera & Braconidae & Cardiochiles & Cardiochiles sp. & 5 & 2.87 \\
\hline
\end{tabular}




\begin{tabular}{|l|l|l|l|c|c|}
\hline & Formicidae & Paratrechina & Paratrechina $\mathrm{sp}$. & 9 & 5.17 \\
\hline & & Pheidole & Pheidole sp. & 14 & 8.05 \\
\hline & & Acantholepis & Acantholepis sp. & 11 & 6.32 \\
\hline & & & Subtotal & $\mathbf{3 9}$ & $\mathbf{2 2 . 4 1}$ \\
\hline & Drosophilidae & Drosophila & Drosophila sp. & 14 & 8.05 \\
\hline & Muscidae & Musca & Musca domestica & 20 & 11.49 \\
\hline & & & Subtotal & $\mathbf{3 4}$ & $\mathbf{1 9 . 5 4}$ \\
\hline & & Blatella & Blatella sp.(nymph) & 2 & 1.15 \\
\hline & & Periplaneta & $\begin{array}{l}\text { Periplaneta } \\
\text { Americana }\end{array}$ & 4 & 2.3 \\
\hline Hemiptera & & & Subtotal & $\mathbf{6}$ & $\mathbf{3 . 4 5}$ \\
\hline & Lygaeidae & Dieuches & $\begin{array}{l}\text { Dieuches } \\
\text { (nymph) }\end{array}$ & 4 & 2.3 \\
\hline & & Blissus & Blissus leucopterus & 2 & 1.15 \\
\hline & & & Subtotal & 6 & $\mathbf{3 . 4 5}$ \\
\hline & & & Grand Total & $\mathbf{1 7 4}$ & $\mathbf{1 0 0}$ \\
\hline
\end{tabular}

Comparison between Insect collected from decomposing African oil bean seed in two environments in Awka, Anambra State from April to June, 2018.

Figure 1 revealed that the total number of insects attracted to asynanthropic environment (218) was higher than those of synanthropic environment (174). There was no significant difference between the number of insects attracted to asynanthropic and synanthropic environment $(\mathrm{P}=0.16)$ 


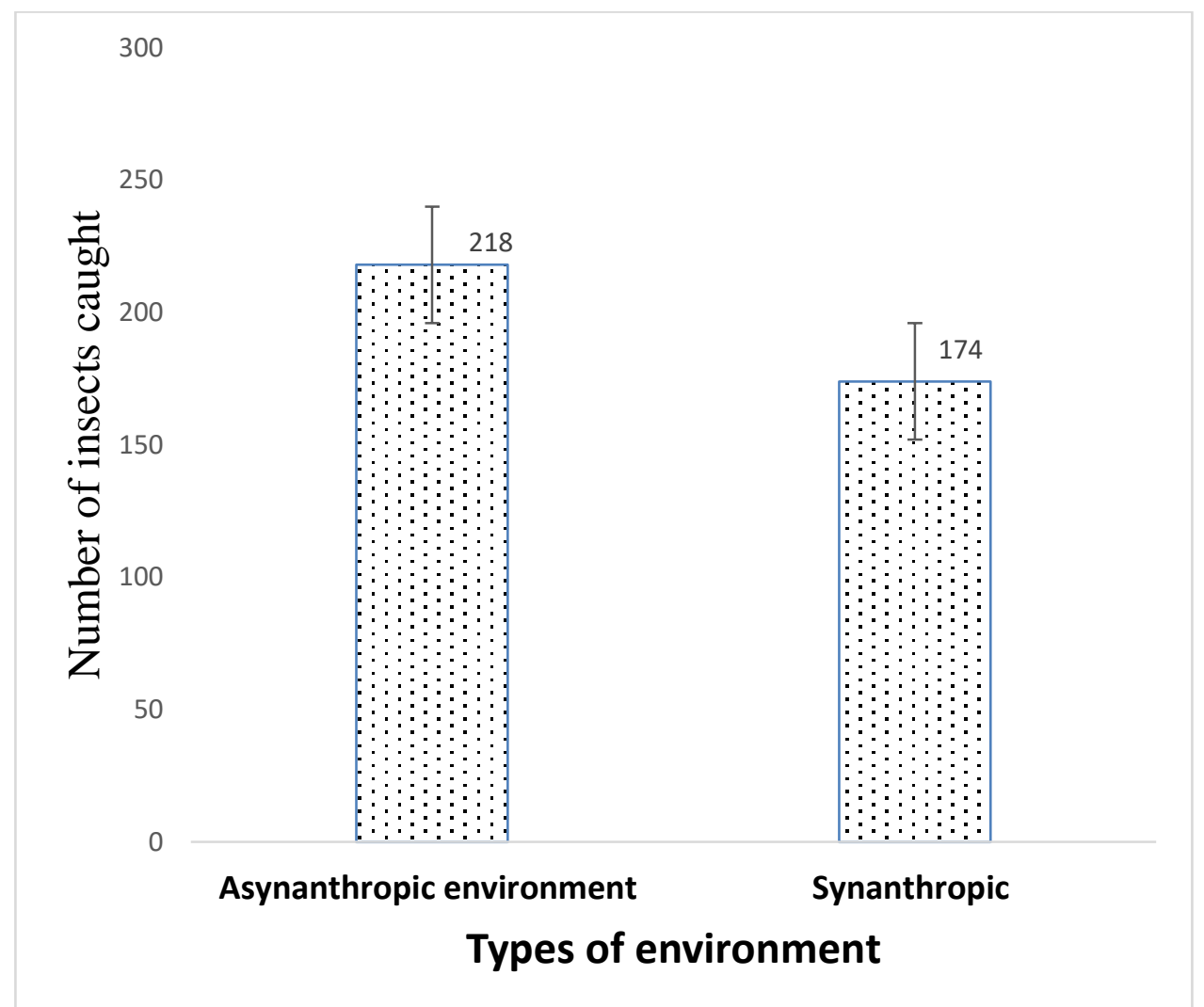

Figure 1: Comparison between Insect collected from decomposing African oil bean seed in two environments in Awka, Anambra State from April to June, 2018.

The result of the minimum duration of the sampled larvae from decomposing sliced fermented oil bean seed in the asynantropic environment is presented in Table 3. The result showed that it the larvae of Musca domestica developed to adult at 33 days while those of Drosophila sp. were 8 days.

Table 3: Minimum Duration of the sampled larvae from decomposing sliced fermented oil bean seed in the asynanthropic environment.

\begin{tabular}{|l|l|l|l|l|}
\hline Family & Species & Larvae & Pupa & Adult Emergence \\
\hline Muscidae & Musca domestica & 7 days & 3 days & 33 days \\
\hline Drosophilidae & Drosophila sp. & 6 days & 2 days & 8 days \\
\hline
\end{tabular}

The species diversity on each substrate is represented in Table 4. Species diversity was higher in the synanthropic environment (2.94) than in the asynanthropic environment (2.83). The Shannon evenness index shows that the insects were not evenly distributed between 0.96 in the asynanthropic environment and 0.82 in the synanthropic environment.

Table 4: Indices of species diversity on decomposing African oil bean seed in the two environments in Awka.

\begin{tabular}{|l|l|l|}
\hline & Synanthropic site & Asynanthropic site \\
\hline $\mathbf{N}$ & 174.00 & 218.00 \\
\hline $\mathbf{S}$ & 19.00 & 17.00 \\
\hline H' & 2.94 & 2.83 \\
\hline J & 0.82 & 0.96 \\
\hline
\end{tabular}

$\mathbf{N}=$ Total number of individual insects on each substrate

$\mathbf{S}=$ Species richness on each substrate

$\mathbf{H}$ '= maximum possible diversity on each substrate

$\mathbf{J}=$ Shannon equitability index/Evenness 


\section{DISCUSSION}

The three hundred and ninety-two (392) individual insects collected from the decomposing sliced fermented African oil bean seed during this study belongs to five orders, fourteen families and twenty-one species. The asynanthropic site recorded a total of 218 insects corresponding to $55.61 \%$ of the total insects population collected while the synanthropic site recorded a total number of 174 insects corresponding to $44.39 \%$ of the total population.

The large number of insects attracted to the decomposing African oil bean seed is due to the fact that oil bean seed serves directly as food source and breeding medium to many insect species while some other insects indirectly depend on the decomposing African oil bean seed by feeding on other insect found on the decomposing substrate (22). More insects of the coleopteran order were recorded. This was in contrast with the works of (23), where lesser number of coleopterans were collected from pitfall trap baited with ogiri from mesquite seed in a fallow plot. More dipterans especially Musca domestica were collected from the synanthropic site and this coincides with (24) who recorded high number of Musca domestica among insect vectors associated with food spoilage in human residence.

The high number of coleopterans recorded in this study agreed with the results of (25) who reported that the high number of captured insects could be due to their habitat and the nature of environment since coleopterans and gryllids not only hide among vegetations, under stones or burrow in the ground, but also are omnivorous feeders. Among the hemipteran species collected were Dieuches sp. (at nymphal stage) and Blissus leucopterus. Dieuches sp. were seen in both synanthropic and asynanthropic environment while Blissus leucopterus were seen in the asynanthropic environment but lacking in the synanthropic environment. (26) also recorded high number of B.leucopterus among the field pest of castor bean. B.leucopterus are voracious seed feeders, hence the name seed bugs (27).

This study revealed that variation exists among the different insects attracted to decomposing fermented African oil bean seed in the two environments. The research also linked the high number of insects recorded to the foraging activities of the insects and for the fact that decomposing fermented oil bean seeds is a good medium for insects oviposition.

\section{CONCLUSION}

Findings from the study showed that certain insects are associated with fermented African oil bean seed. Processed food such as sliced fermented African oil bean seed is a suitable substrate for feeding, egg laying and development of individual insect species such as Musca domestica and Drosophila sp. Large number of insects belonging to different orders are associated with decomposing sliced fermented African oil bean seed and were relatively more abundant in asynanthropic than synanthropic environment in Awka.

\section{REFERENCES}

[1] Enujiugha, V.N., Akanbi, C.T. Compositional changes in African Oil Bean seed (Pentaclethra macrophylla Benth) seeds during thermal processing.(2005). Pakistan Journal of Nutrition; 4:27-31.

[2] Okafor, J.C., Okolonkwo, U.C., Ejiofor, M.A. Evaluation of oils from fermented and unfermented seeds of the African oil bean tree (Pentaclethra macrophylla).(2011).International Tree crops Journal;7:95-101.

[3] Mbajunwa, O.K., Akingbola, K., Mulongoy.,O.G. Starter culture evaluation from the production of ugba from African Oil Beanseed (Pentaclethra macrophylla Benth).(2008).Journal of Science Food Agric; 77:127-132.

[4] Enujiugha, V.N. Nutrient changes during the fermentation of African oil bean (Pentaclethra macophylla Benth) seeds. (2003). Pakistan Journal of Nutrition; 2(5):320-323.

[5] Achinewhu, S. C. Protein quality of African oil bean seed (Pentaclethra macrophylla Benth) seeds. (2006). Riv. Ital. Sostanze Grosse; $2: 54-59$.

[6] Onwuliri, V. A., Ekpenyong, Z. S. C., Okoye, K. I.,Ekwenchi, M. M. Comparative Study on Two Nigeria Local Brands of Beer.(2016). Nigeria journal Biotechnology; 2: 13-18.

[7] Njoku, H.O., Okemadu, C.P. Biochemical changes during the natural fermentation of the African oil bean seeds (Pentaclethra macrophylla Bentham) for ugba production.(2009). Food Microbiol;7: 1-4.

[8] Ewuim, S. C. A study of the insect fauna of the Permanent Site of Nnamdi Azikiwe University, Awka, Ph.D. Thesis. Nnamdi Azikiwe University Awka. (2004). 269 pp.

[9] Omoloye, A. A. Fundamentals of Insect Pest Management.(2008). Corporate Publishers, Lagos, 223pp.

[10] Obeta, J.A. A note on the microorganisms associated with the fermentation of seeds of the African oil bean tree (Pentaclethra macrophylla).(2013). J Appl Bacteriol;54:433-435.

[11] Ogbulie, E.C. Evaluation of packaging materials for the preservation of African oil bean (pentaclethra macrophylla) for the production of ugba.(2014). Journal of innovation life science; 3:110-118.

[12] Bornemissza, G.F. The Australian Dung Beetle Research unit of Pretoria.(2009). South African Journal of sciences;75:257-260.

[13] Olasupo, U.A., Smith S.I., Akinsinde, K.A. Examination of Microbial Status of Selected Indigenous Fermented Foods In Nigeria.(2016).

Journal of food science; 8:85-93

[14] Okorie, P.C., Olasupo, N.A., Anike, F.N. Incidence of enteric pathogens in ugba,a traditional fermented food from African oil bean seeds(Pentaclethra macrophylla Benth).(2007). International Journal of Food Contamination; 4:12-20

WWW.scirj.org

(C) 2019, Scientific Research Journal

http://dx.doi.org/10.31364/SCIRJ/v7.i4.2019.P0419XX 
[15] Monago, C.C., Ogbomah, P.A.,Joshua, P.E. Effect of African Oil Beanseed (Pentaclethra Macrophylla) On Blood Cholesterol Level In Rats(2004). Global Journal of Pure and Applied Science; 10:165-168

[16] Joson, L.C.Effects of Processing Methods on the Quality of Ugba(Pentaclethra macrophylla Benth.).(2015). International Journal of food contamination;5:12-17.

[17] Ewuim, S.C., Osondu, A. Studies On The Environmental Implications of Ants (Hymenoptera:Formicidae) Associated With Two Synanthropic Environments In Awka, Nigeria.(2008). Animal Research International; 5(3):908-912.

[18] Aslam, B.T. The Lepidoptera Fauna Associated With Calluna Vulgaris : Effects Of Plant Architecture On Abundance And Diversity.(2009). Ecological Entomology; 23(4): 377-385.

[19] Byrd, J.H., Castner, J.L. Forensic entomology. The utility of arthropods in legal investigations. (2001).CRC Press, New York, New York, 40pp.

[20] Allen, O. N., Allen, E. K. Pentaclethra macrophylla Benth. In: The leguminosae. A source book of characteristic use and nodulation. (2007). Macmillan London, p. 136- 138.

[21] Akunne, C.E., Ewuim, S.C., Chukwunyere, I.C., Abajue, M.C., Ononye, B.U. Efficacy of Ogiri Produced From Mesquite Seed As Bait In Trapping of Insects In A Fallow Plot In Awka.(2014). Animal Research International; 11(2):1994-1997.

[22] Borror, D., Triplehorn, C.,Johnson, N. An introduction to the study of insects.(2002). Saunders college publishing Press, Arkasas, 800pp.

[23] Boorman, J. West Africa Insects. (1981).Longman Group Limited London.

[24] Chauhan, U.K. A study of insects associated with some decaying fleshy fruits. (2006). Environmental and Biodiversity; 35:268-271.

[25] Keay, R.W.J. Nigerian Trees. (1989). Claredon Press, UK. 281 pp.

[26] Morales, G.E., Wolff, M. Insects Associated with the composting process of solid urban Waste separated at the source. (2010). Rev.Bras.Entomol.;54:4-15

[27] Fincher, G.T. The potential value of dung beetles in pasture ecosystems.(2011). Journal of the Georgia Entomological society; 16:316-333 